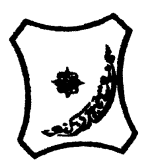

Bayero Journal of Pure and Applied Sciences, 10(2): 38 - 42

Received: June, 2017

Accepted: October, 2017

ISSN $2006-6996$

\title{
ADULTICIDAL POTENTIALS OF DICHLOROMETHANE EXTRACTS OF SOME SELECTED PLANT LEAVES AGAINST CU/eX MOSQUITOES
}

\author{
${ }^{1}$ Ahmadu Bukar and ${ }^{2}$ Zainab Tukur \\ ${ }^{1}$ Department of Biology Education, Federal College of Education (Technical) Potiskum, Yobe State. Nigeria \\ ${ }^{2}$ Department of Biological Sciences, Bayero University Kano, Kano State. Nigeria. \\ *Correspondence author: ahmadbukar@gmail.com
}

\begin{abstract}
Culex mosquitoes are vectors of Lymphatic filariasis and Japanese encephalitis diseases and the control of these diseases using synthetic chemical insecticides such as Pyrethroids results in development of resistance by the mosquitoes and polluting the ecosystem. This research was aim at evaluating the adulticidal potentials of dichloromethane extracts of some selected plant leaves against Culex mosquitoes. The results of the phytochemical screening analysis of the dichloromethane extracts shows that, Cymbopogon citratus, Mentha piperita and Ocimum citriodorum contained the highest number of phytochemicals four (4) each, followed by Lamium pupureum and Zingiber officinale having three (3) the last extracts having the least phytochemicals is Senna occidantalis which contains only two (2). The results of the adulticidal bioassay of the extracts shows that Cymbopogon citratus exhibited the highest adulticidal activities against the Culex mosquitoes tested at the $L C_{50} 5.721 \mathrm{mg} / \mathrm{ml}$ and $L C_{90} 211.703 \mathrm{mg} / \mathrm{ml}$. The percentage mortality was recorded highest at the highest concentration $20 \mathrm{mg} / \mathrm{ml}(87 \%)$, followed by $10 \mathrm{mg} / \mathrm{ml}(74 \%)$ and $5 \mathrm{mg} / \mathrm{ml}(43 \%)$. The mean average mortality and standard error were also recorded at $21.7 \pm 0.47,18.5 \pm 3.01$ and $10.7 \pm 1.37$ respectively. From these results, it can be concluded that, the adulticidal activity of an extract depends on the solvent used in the extraction. Cymbopogon citratus extract was an excellent potentials for controlling Culex mosquitoes. Therefore we recommend that it should be used to control Culex mosquito in the affected areas. Key words: Adulticidal, Culex mosquito, Dichloromethane, Extracts, Phytochemicals
\end{abstract}

\section{INTRODUCTION}

Botanical phytochemicals with adulticidal, larvicidal and pupicidal potential are now given due attention and are recognized as potent alternative insecticides to replace the synthetic insecticides in mosquito control programs due to their excellent performance both in the field and laboratory (Mehlhorn et al., 2005). The uses of naturally occurrin compounds from plant sources have shown promise to be used as commercial insecticides, such as azadiractin, pyrethrins, rotenone, nicotine and toosendani (Devand, 1997; Koul and Walia, 2009). Mosquitoes have been known to cause serious diseases such as malaria, Japanese encephalitis, filariasis, dengue and yellow fever. These diseases remain the major sources of illness and death in developing countries. Such vector borne diseases contribute to the major economic lost in the tropical and subtropical countries (Ghosh et al., 2012; Kundu et al., 2013). Mosquitoes are one of the haematophagous insects in the group of arthropods and they transmit parasites and pathogens which continue to have devastating impact on human beings (Service, 1983).

Among these diseases however, lymphatic filariasis is transmitted by Culex quinquefasciatus Say. That infects 80 million people annually of which 30 million cases exist in seriously chronic infection. Culex quinquefasciatus is a worldwide vector that also causes bancroftian filariasis in the tropical and subtropical countries. Filariasis transmitted by Wucheria bancrofti (Cobbald), is a helminth that lives and develops in the lymph glands and vessels inducing edemas by lymph obstruction. In India alone 25 million people harbor microfilaria (mf) and nineteen million people suffer from filarial disease manifestations (NICD, 1990).

Another serious disease transmitted by culex mosquitoes is Japanese encephalitis (JE) which is caused by outbreaks that occurs often in 14 Asian countries with more than 3,060 million people at the high risk of the infection (Sabesan, 2003). This disease is a major public health problem which draws concerns due to its high epidemic potential, high case of fatality and neuropsychiatric sequel among peoples that survives the disease. The annual incidence and mortality estimates for JE are 30,000-50,000 and 10,000 , respectively, (Solomon, 2004). Hence, there is urgent need for providing other ways of controlling the population of Culex mosquitoes which will be safe to the ecosystem. Therefore, this research is a way forward in providing alternative control measures of the population of the Culex mosquitoes using adulticide method.

\section{MATERIALS AND METHODS}

Plant Samples Collection

The six plant species were obtained along Yahaya Gusau Road and Kano State Polytechnic garden adjacent to Gadon kaya, junction Gwale Local Government, Kano State. Nigeria. And were authenticated in the Department of Plant Sciences, Bayero University, Kano. Nigeria. 
Bajopas Volume 10 Number 2 December, 2017

Table 1 The selected plants and their identification numbers

\begin{tabular}{|c|c|c|c|c|}
\hline $\mathrm{S} / \mathrm{N}$ & Botanical name & Common name & Family name & $\begin{array}{l}\text { BUK Herbarium } \\
\text { Accession Number }\end{array}$ \\
\hline 1 & Cymbopogon citrates & Lemon grass & Poaceae & BUKHAN 0234 \\
\hline 2 & Mentha piperita & Spearmint & Lamiaceae & BUKHAN 0337 \\
\hline 3 & Senna occidentalis & Coffee senna & Lamiaceae & BUKHAN 0073 \\
\hline 4 & $\begin{array}{l}\text { Ocimum citriodorum } \\
\text { L. pupureum }\end{array}$ & $\begin{array}{c}\text { Lemon Basil } \\
\text { Purple Deadnettle }\end{array}$ & $\begin{array}{l}\text { Fabaceae } \\
\text { Lamiaceae }\end{array}$ & $\begin{array}{l}\text { BUKHAN } 0298 \\
\text { BUKHAN } 0306\end{array}$ \\
\hline 6 & Zingiber officinale & Ginger & Zingiberaceae & BUKHAN 0296 \\
\hline
\end{tabular}

Plant Leaves Preparation Extract

The plants leaves were washed with tap water and dried in an oven $30-60^{\circ} \mathrm{C}$. The dried plant leaves were grinded into powder using electric blender and stored in dark air tight containers and stored at room temperature until use (Ajaegbu et al., 2016)

\section{Extraction of the Plant Materials}

The powdered plant leaves were extracted separately with $25 \mathrm{ml} / 100 \mathrm{~g}$ of Dichloromethane using Soxhlet apparatus by Sonification. Whatman No.1 filter papers were used to filter the extracts. The extracted plants leaves were dried and stored under normal room temperature at $30^{\circ} \mathrm{C}$ until bioassay (Sukumar et al., 1991)

\section{Mosquitoes Samples Collection}

Culex mosquitoes were collected at various breeding sites within the study area at different locations namely: Sewage at Bayero University Kano girls hostel, Haurar wanki and Haurar shanu road side Sewages along BUK road, Gwale local government, Kano State according to (WHO, 1982).

\section{Rearing Mosquitoes}

White plastic container with wide mouth covered with a rubber mesh sized 1 "by $4 \mathrm{~cm}$ were used to rear the Culex mosquitoes in the Postgraduate laboratory, Biological sciences Department Bayero University, Kano. The larvae were fed with yeasts powder at a ratio of $3: 1$. Adults were provided with $10 \%$ sucrose solution (WHO, 1982).

\section{Phytochemical Screening}

The Phytochemical screening of the extracts were conducted in the Department of Biochemistry Laboratory Bayero University Kano, for the detection of the presence of the following secondary metabolites Anthroquinones, Steroids,Terpenoids, Saponins, Tannins, Flavonoids, Alkaloid, Soluble starch (Murugan et al., 2012).

\section{Adulticide Bioassay}

The adulticidal bioassay was conducted at Central laboratories complex, Bayero University, Kano. The adulticidal activity of the six experimental plants leaves Dichloromethane extracts were evaluated following the WHO standard (WHO, 2006). Two and half millilitre $(2.5 \mathrm{ml})$ of the test concentrations of 5 ,
10 and $20 \mathrm{mg} / \mathrm{ml}$ were impregnated into No.1 Whattsman filter paper $(12 \times 15 \mathrm{~cm})$ at four (4) replicates and an empty No.1 Whattsman filter paper $(12 \times 15 \mathrm{~cm})$ were used as control. The leaves extracts impregnated papers were air dried for 5-10 minutes and then inserted into the exposure tube in the WHO test kit. Twenty five (25) 2-5 day old blood starved female Culex quinquifasciatus mosquitoes were introduced into the holding tube and held for 5-10 minutes to acclimatize. The Culex mosquitoes were then transferred by gentle blowing from the holding tube into the exposure tube and allowed to stand for one (1) hour. The mosquitoes were then transferred back to the holding tube to recover for 24 hours. A pads of cotton soaked with $10 \%$ glucose solution were placed on the mesh screen to feed the recovering mosquitoes. At the end of the 24 hours recovery period, the numbers of death mosquitoes were recorded and the percentage mortalities were also calculated.

\section{Statistical Analysis}

The adult mosquito mortality data were subjected to probit analysis of calculating $\mathrm{LC}_{50}, \mathrm{LC}_{90}$, mean and Standard error (S.E) at 95\% using SPSS version 20.0 Result with $\mathrm{P}<0.05$ was considered to be statistically significant.

\section{RESULTS \\ Phytochemical Screening of Ethanol Plant Extract}

The analysis of the phytochemicals contained in the dichloromethane extracts screened (Table 2), shown the occurrence of eight (8) phytochemicals in the six extracts. Across all the extracts, the number of phytochemicals presents ranges from (4 to 2). The result further shown that $C$. citrates, M. Piperita, and $O$. citriodorum contains the highest number of phytochemicals (4) in each, with $C$. citrates containing (terpenoids, saponins, Tennins and alkaloids), $M$. Piperita having (saponins, tannins, flavonoids and alkaloids) while $O$. citriodorum having (saponins, tannins, flavonoids and alkaloids). The extract having the least phytochemicals was $S$. occidentalis which contains only (2) includes (tannins and alkaloid). The remaining are $L$. purpureum and $Z$. officinale with both having (3) each. L. purpureum contained (Saponins, Tannins and alkaloids) while $Z$. Officinale having (tannins, flavonoids and alkaloids). 
Bajopas Volume 10 Number 2 December, 2017

Table 4. Phytochemical screening of dichloromethane plant extracts

\begin{tabular}{|c|c|c|c|c|c|c|c|c|}
\hline \multirow[b]{2}{*}{ Plant extracts } & \multicolumn{8}{|c|}{ Phytochemicals } \\
\hline & Ant & Str & Terp & Sap & Tannins & Flavonoids & Alkaloids & $\begin{array}{l}\text { Soluble } \\
\text { Starch }\end{array}$ \\
\hline C. citrates & - & - & + & + & + & - & + & 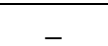 \\
\hline M. piperita & - & - & _ & + & + & + & + & - \\
\hline S. occidentalis & _ & _ & _ & _ & + & _- & + & - \\
\hline O. citriodorum & - & - & - & + & + & + & + & - \\
\hline L. pupureum & - & _ & - & + & + & - & + & - \\
\hline Z. officinale & - & - & - & - & + & $\overline{+}$ & + & - \\
\hline
\end{tabular}

Key: Positive $(+)=$ Present, Negative $(-)=$ Absent, Ant = Anthroquinone, Str = Steroids, Sap = Saponins, Terp $=$ Terpenoides

The result of the probit analysis of the adulticidal activities of the dichloromethane extracts shown that Cympodogon citratus exhibited the highest adulticidal activities against the Culex mosquito tested at the $\mathrm{LC}_{50} 5.721 \mathrm{mg} / \mathrm{ml}$ and $\mathrm{LC}_{90} 211.703 \mathrm{mg} / \mathrm{ml}$, the percentage mortality was recorded highest at the higher concentration $20 \mathrm{mg} / \mathrm{ml}(87 \%)$, followed by $10 \mathrm{mg} / \mathrm{ml}(74 \%)$ and $5 \mathrm{mg} / \mathrm{ml}(43 \%)$. The mean average mortality and standard error were also recorded at $21.7 \pm 0.47,18.5 \pm 3.01$ and $10.7 \pm 1.37$ respectively.

Mentha piperita was recorded second potent extract at the $\mathrm{LC}_{50} 20.174 \mathrm{mg} / \mathrm{ml}$ and $\mathrm{LC}_{90} 418.214 \mathrm{mg} / \mathrm{ml}$, the percentage mortality was highest at the higher concentration $20 \mathrm{mg} / \mathrm{ml}(48 \%), 10 \mathrm{mg} / \mathrm{ml}(42 \%)$ and $5 \mathrm{mg} / \mathrm{ml}(26 \%)$ with average mean mortality and standard error as $12.0 \pm 1.68,10.5 \pm 0.95$ and $6.5 \pm 1.19$, these results are in comparison with the other four (4) plants extracts, among which is Senna occidentalis which recorded the $\mathrm{LC}_{50} 90.759 \mathrm{mg} / \mathrm{ml}$ and $\mathrm{LC}_{90} 835.541 \mathrm{mg} / \mathrm{ml}$ with the percentage mortality was highest at the higher concentration $20 \mathrm{mg} / \mathrm{ml}$
$(17 \%), 10 \mathrm{mg} / \mathrm{ml}$ and least at the lower concentration $5 \mathrm{mg} / \mathrm{ml}(3 \%)$. The mean average mortality and the standard error were recorded at $4.2 \pm 1.31,3.5 \pm 0.86$ and $0.7 \pm 0.25$. The Ocimum citriodorum recorded the $\mathrm{LC}_{50} 272.006$ and $\mathrm{LC}_{90} 31972.3$ the percentage mortality was highest at the higher concentration of $20 \mathrm{mg} / \mathrm{ml}(24 \%), 10 \mathrm{mg} / \mathrm{ml}(19 \%)$ and $5 \mathrm{mg} / \mathrm{ml}(14 \%)$. The mean average mortality was $6.0 \pm 0.81,4.7 \pm 0.47$ and $3.5 \pm 0.28$ respectively. These results were slightly greater than the result obtained in Lamium puperium with the $\mathrm{LC}_{50} 132.715$ and $\mathrm{LC}_{90} 3427.019$ and the percentage mortality obtained at the higher concentration $20 \mathrm{mg} / \mathrm{ml}(23 \%), 10 \mathrm{mg} / \mathrm{ml}(15 \%)$ and $5 \mathrm{mg} / \mathrm{ml}(10 \%)$. The mean average mortality was at $5.7 \pm 1.10, \quad 3.7 \pm 1.03$ and $2.5 \pm 0.64$ respectively. Zingiber officinale also recorded LC $_{50} 611.969$ and $\mathrm{LC}_{90}$ 66648.413. Percentage mortality was least at the higher concentration $20 \mathrm{mg} / \mathrm{ml}(17 \%)$, followed by $10 \mathrm{mg} / \mathrm{ml}(14 \%)$ and $5 \mathrm{mg} / \mathrm{ml}(9 \%)$. The mean average mortality and the standard error are at $4.2 \pm 0.25,3.5 \pm 0.28$ and $2.25 \pm 0.47$ respectively.

Table 6. The Adulticidal activities of different plants dichloromethane extracts against Culex quinquifasciatus after 24hrs exposure period

\begin{tabular}{|c|c|c|c|c|c|c|c|}
\hline & Plant extract & $\begin{array}{l}\text { Concentration } \\
(\mathrm{mg} / \mathrm{ml})\end{array}$ & Mean \pm S.E & \%Mortality & $\mathrm{LC}_{50}$ & $\mathrm{LC}_{90}$ & $x^{2}$ \\
\hline \multirow{3}{*}{1} & & 5 & $6.5 \pm 1.19$ & 26 & & & \\
\hline & M. piperita & 10 & $10.5 \pm 0.95$ & 42 & 20.174 & 418.214 & 11.5 \\
\hline & & $20^{\circ}$ & $12.0 \pm 1.68$ & 48 & & & \\
\hline \multirow{4}{*}{2} & & 5 & $10.7 \pm 1.37$ & 43 & 5.721 & 21.703 & 26.6 \\
\hline & C. citrates & 10 & $18.5 \pm 3.01$ & 74 & & & \\
\hline & & 20 & $21.7 \pm 0.47$ & 87 & & & \\
\hline & & 5 & $3.5 \pm 0.28$ & 14 & & & \\
\hline \multirow[t]{4}{*}{3} & O. citriodorum & 10 & $4.7 \pm 0.47$ & 19 & 272.006 & 31972.3 & 2.8 \\
\hline & & 20 & $6.0 \pm 0.81$ & 24 & & & \\
\hline & . & 5 & $0.7 \pm 0.25$ & 3 & & & \\
\hline & & 10 & $3.5 \pm 0.86$ & 13 & & & \\
\hline \multirow[t]{3}{*}{4} & S.occidentalis & 20 & $4.2 \pm 1.31$ & 17 & 90.759 & 835.541 & 12.5 \\
\hline & & 5 & $2.5 \pm 0.64$ & 10 & & & \\
\hline & & 10 & $3.7 \pm 1.03$ & 15 & & & \\
\hline \multirow[t]{3}{*}{5} & L. pupureum & 20 & $5.7 \pm 1.10$ & 23 & 132.715 & 3427.019 & 9.546 \\
\hline & & 5 & $2.25 \pm 0.47$ & 9 & & & \\
\hline & & 10 & $3.5 \pm 0.28$ & 14 & & & \\
\hline 6 & Z. officinale & 20 & $4.2 \pm 0.25$ & 17 & 611.969 & 66648.413 & 1.966 \\
\hline
\end{tabular}


Bajopas Volume 10 Number 2 December, 2017

\section{DISCUSSION}

The results of the phytochemical screening of the six plants extracts of dichloromethane extracts carried out in this study (Table 2) was in agreement with the findings of Babeet and Rekha (2010) on the qualitative and quantitative phytochemicals screening of Alagium salviifolium L. extracted with Petroleum ether, Benzene, Chloroform, Ethanol and Equeous to determine the presence of Proteins, Carbohydrates, Tannins, Flavonoids, Alkaloids and Steroids. They obtained different number of phytochemicals at different extractive value. Peeyush et al. (2011) also stated that the potentials of extract as insecticide relies on the activity of the solvent used in the extractions which determines activity of plant extract as bioinsecticide.

The result of the adulticidal bioassay of the M. piperita dichloromethane extract in this study was in agreement with the findings of the work of Yang et al., (2005). And the adulticidal activities of Cympodogon citratus dichloromethane in this study was in agreement with the result obtained by Annick et al. (2013) who tested various essential oils including $C$. citrates against $A n$. gambiae "kisumu" and found the mortality rate of the An. gambiae "Kisumu" varies from $72.5 \%$ at lower dose of $0.0 \%$ $\mathrm{w} / \mathrm{w}$ and increased with the increase in dosage. At $0.50 \%$, the mortality reached $100 \%$ for $C$. citrates. Similarly, it's also in agreement with the result of the findings of other workers (Karunamoorthi and Ilango 2010; Justin et al., 2011 and Sharaby, 2011). The activity of this plant in this work could be attributed to the number of phytochemicals found in the plant extract

However, the number of the phytochemical are less compare to the total number of the phytochemiocals tested but the high activity might be due to the high quantity of the Secondary metabolites found.

The result of the adulticidal activities of Ocimum citriodorum dichloromethane extracts was in agreement with the findings of the study by Bhagai (1992) who reported the activity of $\boldsymbol{O}$. Sanctum leave extract causing morphogenetic abnormalities and growth regulation against $4^{\text {th }}$ instar larvae of $A n$. Stephensi in India.

Similarly, the low activity (32\%) (24\%) observed this plant might be due to the concentration used, $(20 \mathrm{mg} / \mathrm{ml})$ highest, but when high concentration is used this plant could give a high activity. This claim was in agreement with the finding of the work which

\section{REFERENCES}

Annick, D. B., Sven, M., Hounnankpon, Y., Pelagie, M. B., Martin, C. A., Norbert, D. K., Felicien, A. and Dominique, C. K. S. (2013): Chemical composition and insecticidal activity of plant essential oils from Benin against Anopheles gambiae (Giles), journal of Parasites and Vectors. 2013, 6:33

Ajaegbu, E. E., Simon, P. Y. D., Ikemefuna, U. C. and Festus, B. C. O. (2016) Mosquito adulticidal activity of the leaf extracts of Spondias mombin L. against reported that the extracts of $O$. Sanctum at $200 \mathrm{mg}$ was found to have stopped the post embryonic development of the insect larvae. The low activity of dichloromethane extract of $S$. occidentalis adulticidal bioassay in this could be attributed to the few number of phytochemical (2) extracted in the plant as earlier mentioned. It might also due to the low quantity of the secondary metabolites.

The result of the Lamium Purpureum dichloromethane extracts in this study was not in agreement with findings of Jones et al. (2012): which stated that the extracts of $L$. amplexicaule and $L$. purpureum had no phytotoxic potential against fire ants. Therefore, the activity observed in the Lamium purpurium ethanol extract in this study as opposed to the previous study could be due to the insects tested. (Culex quinquefasciatus and fire ant)Therefore, other research should be conducted to test the activity of this plant extract against the two insects.

The result of $Z$. officinale dichloromethane extracts was in agreement with the findings of the study by Veena et al., (2005) who found that the Essential oils of Zingiber officinale and Rosmarinus officinalis were effective as ovicidal and repellent and not effective in adulticidal activities against mosquito vectors.

\section{CONCLUSION AND RECOMMENDATION}

In this research the findings reveals that the phytochemicals present in a given extracts depends on the solvents used in the extraction processes which is responsible for the bioactivity of the extract against Culex mosquitoes as it was observed in Cymbopogon citrates and other extracts used in this study. Therefore it can be concluded that $C$. citratus dichloromethane extracts possess insecticidal potentials. Hence, we recommend it to be used as potential bioinsecticide against Culex mosquitoes at a higher concentration of $20 \mathrm{mg} / \mathrm{ml}$ in the endemic endemic areas.

\section{Contribution of Authors}

Ahmadu Bukar collect sample, undertook the study, analyzed the data and draft the manuscript. Zainab Tukur supervised and designed the study. Both authors have read and approved the manuscript.

\section{Conflict of Interest}

The authors Ahmadu Bukar and Zainab Tukur declare that they do not have conflict of interest.

\section{Acknowledgement}

The authors are thankful to Mr. Usman Bawa for his assistance in Statistical Analysis and Motivation.

Aedes aegypti L. and isolation of active principles Journal of Vector Borne Disease 53. $17-22$

Babeet S. T., and Rekha V. (2010) phytochemical evaluation and quantification of primarymetabolites of alangium salviifolium, international journal of pharma and bio sciences. vol.1/issue-3

Bhagai, O. P. (1992): National Academy of Agricultural Sciences. An International BiAnnual Journal of Life Science. 
Devand, S., Koul, O., (1997): Insecticides of Natural Origin. Harwood Academic Publishers, Amsterdam, $365 \mathrm{pp}$

Ghosh, A., Chowdhury, N., Chandra, G. (2012): Plant extracts as potential mosquito larvicide. Indian J. Med. Res. 135, 581-598

Jones, C., Woods, K. and Setzer, W. (2012): A chemical ecological investigation of the allelopathic potential of Lamium amplexicaule and Lamium purpureum. Open Journal of Ecology, 2, 167-177.

Justin, K., Anastasie, G., Adeline, U., Viateur, U. and Polycarpe, N. (2011): Insecticidal effects of essential oils of Pelargonium graveolens and Cymbopogon citratus on Sitophilus zeamais (Motsch.), African Journal of Food Science 5(6): 366 - 375,

Karunamoorthi, K. and Ilango, K. (2010): Larvicidal activity of Cymbopogon citrates (DC) Stap. and Croton macrostachyus Del. Against Anopheles arabiensis Patton, a potent malaria vector. European Review for Medical and Pharmacological Sciences. 14: 57-62

Koul, O., Walia, S., (2009): Comparing impacts of plant extracts and pure allelochemicals and implications for pest control. Sci. Nutr. Nat.Resour. 4 : (049), 1-30.

Kundu, M., Rawani, A., Chandra, G. (2013): Evaluation of mosquito larvicidal activities of seed coat extract of Cassia sophera L. J. Mosq. Res. 3, 76-81.

Mehlhorn, H., Schmahl, G., Schmidt, J., (2005): Extract of the seeds of the plant Vitexagnus castus proven to be highly efficacious as a repellent against ticks, fleas, mosquitoes and biting flies. Parasitol. Res. 95, 363365

Murugan, K., Mahesh, K. P., Kovendan, K., Amerasan, D., Subrmaniam, J. (2012) Larvicidal, pupicidal, repellent and adulticidal activity of Citrus sinensis orange peel extract against Anopheles stephensi, Aedes aegypti and
Culex quinquefasciatus (Diptera: Culicidae). Parasitol Res 111: 1757-1769.

NICD: (1990): Proceedings of the National Seminar on Operation Research on Vector Control in Filariasis, New Delhi.

Peeyush, K., Sapna, M., Anushree, M. and Santosh, S. (2011): Insecticidal properties of Mentha species. A review, Industrial Crops and Products 34:802- 817

Sabesan, S. (2003): Forecasting mosquito abundance to prevent Japanese encephalitis. Curr. Sci. 84 (9), 1172-1173.

Service, M. W.,(1983): Vectors Management in the Tropics, pp.265-280

Sharaby (2011): Anti-Insect Properties of the Essential Oil of Lemon Grass, Cymbopogen citratusAgainst the Lesser Cotton Leaf worm Spodoptera exigua ( $\mathrm{Hbn})$ Laboratory of Pests and Plant Protection, National Research Centre, Dokki, Cairo, Egypt.

Solomon, T. (2004): Flavivirus encephalitis. J. Med. $351,370-378$.

Sukumar, K., Perich, M. J., Boobar, L. R., (1991) Botanical derivatives in mosquito control: $\mathrm{A}$ review. Journal of American Mosquito Control Association 7(2): 210-37.

Veena, P. A. K., Tripathi, K. and K., Aggarwal, K. P.S. (2005): Insecticidal, repellent and oviposition-deterrent activity of selected essential oils against Anopheles stephensi, Aedes aegypti and Culex quinquefasciatus. Bioresource Technology 96 1749-1757

World Health Organization (WHO) (1982) GENEVA Ofset Publication No. 66

WHO (2006): Guidelines for testing mosquitoes aducticides for indoor residual spraying and treatment of Mosquito nets. Genava: world health organization

Yang, P., Ma, Y. and Zheng, S., (2005): Adulticidal activity of five essential oils against Culex pipiens quinquefasciatus. J. Pestic. Sci. 30, 84-89 